de inmersión temporal. Libro de Reportes Cortos. 5to Coloquio Internacional de Biotecnología Vegetal: pp 185-187.

ESCALONA. M.; LORENZO, J.C.; GONZALEZ, B.; DAQUINTA, M.; GONZALEZ, Y; ESJARDINS, J.L.; BORROTO, C.G. 1999. Pineapple (Ananas comosus L. Merr.) micropropagation in temporary immersion systems. Plant Cell Reports $18: 743-748$. antivitrifying agents. Canadian Journal Plant Science 73: 231-235.

JIMENEZ, E.; PEREZ, N.; M DE FERIA, R.; BALBOA, R.; CAPOTE, A.; CHAVEZ, M.; QUIALA, E.; PEREZ, J.C. 1998. Improved production of potatoes (Solanum tuberosum L.) microtubers using temporary immersion systems. Plant Cell, Tissue and Organ Culture 54 :

LORENZO, J C.; GONZALEZ, B.; ESCALONA, M.; TEISSON. C.; ESPINOSA, P.; BORROTO, C.G. 1998. Sugar cane shoot formation in an improved Temporary Immersion System. Plant Cell, Tissue and Organ Culture. 54 : 197-200.

TEISSON C.; ALVARD, D. 1995. A new concept of plant in vitro cultivation liquid medium: Temporary Immersion. In: Terzi, M.; Cella, R.; Falavigna, A. (eds.). Current Issues in Plant Molecular and Cellular Biology. Netherland, Kluwer Academic Publishers, pp. 105-109

\title{
LOGISTICA EN LA COMERCIALIZACIÓN Y EXPORTACIÓN DE FLORES
}

\section{LOGISTICS IN SALE AND EXPORT OF FLOWERS}

\author{
Puiggros, A., Gerente General AC Mater. Av. Lo Narváez s/n, Olmué - V Región. \\ E-mail:apv@acmater.cl
}

La logística en la comercialización de flores cortadas debe ser analizada en un contexto que abarque todos los procesos involucrados en el negocio propiamente tal, desde la planificación inicial de la compra del material vegetal inicial hasta la obtención de la re-compra.

En la actualidad los manejos logísticos para el mercado nacional y para el mercado de exportación de flores difieren enormemente, ¿Es esto lógico? ¿Por qué una flor que se comercialice en Chile debe ser manejada en forma distinta a la que se vende en otros países?

Para poder analizar los diferentes aspectos logísticos dentro del negocio de producción y comercialización de flores hay que identificar los aspectos claves y clasificarlos según si son productivos, de poscosecha o comerciales.

¿Qué hacer para poder mantenerse en el tiempo en el negocio de producción y comercialización de flores de corte? Hay que lograr lo que he definido las tres "C" del negocio: Compromiso,
Consistencia y Cumplimiento.

Los principales puntos a abordar son los siguientes:

* La comercialización de flores en el contexto general del negocio. No solo hay que vender, la sustentabilidad del negocio va más allá que eso.

* Nociones del concepto de logística. Hay que tener los límites bien claros.

* Aplicación del concepto DMAMC: Todo factor relevante debe ser Definido, Medido, Analizado, Mejorado y Controlado.

* La logística en un proceso de exportación de flores frescas. Análisis de los puntos críticos en el proceso de exportación.

* La logística en un proceso de comercialización de flores a nivel local. Análisis de la realidad local.

* Diferencias entre el proceso exportador y la venta local.

* ¿Cómo mantenerse en el tiempo? 